\title{
Strategies for Remediating Environmental Pollution, and Applicable Indicators for Identifying them: Mini Review
}

\author{
Timothy E Egbo*1, Ali Saber ${ }^{2}$, Carrie A Sanders ${ }^{1}$, Rajnish Sahu ${ }^{1,3}$, Yazeed Abdelmageed ${ }^{1}$ and Boakai K Robertson $^{1}$ \\ ${ }^{1}$ Department of Biological Sciences, Alabama State University, Montgomery, AL USA
}

${ }^{2}$ Department of Civil and Environmental Engineering and Construction, University of Nevada, Las Vegas, USA

${ }^{3}$ Department of Biological Science, Center for Nanobiotechnology Research, Alabama State University, Montgomery, AL USA

Received: 眥 January 07, 2019; Published: 眥 January 18, 2019

*Corresponding author: Timothy E Egbo, Department of Biological Sciences, USA

\begin{abstract}
Toxic chemicals are mostly released into the air, water, and soil due to anthropogenic activities or natural processes. These chemicals can be classified as organic or inorganic pollutants that can cause serious environmental contamination and render an environment inhabitable. Human activities help to proliferate chemical discharge (directly or indirectly) such as solvents, pesticides, and fossil fuels into the environment. Different approaches have been described as a means of environmental restoration such as the physical, chemical, and biological methods; however, transfer of contaminants from the point of source to an uncontaminated site limits this process. With the advent of biotechnology, a clear approach towards the use of microorganisms or plants for environmental restoration have been proposed and tested. Bioremediation is a very broad area of biotechnology that focuses on using phytoremediation and microorganisms as a strategy for environmental clean-up. For the most part, microorganisms play an important role in the transformation of organic and inorganic compounds in the environment. Some microorganisms use metals as a source of energy, and in return transforms it into a less toxic form. The time it takes to clean up a contaminated site depends on the concentration of the contaminants, the contaminated area, and among other physical conditions.

For an effective bioremediation, these factors have to be in place. Bioremediation can be applied at the site of contamination (in-situ) or through the removal of the contaminants to a different location (ex-situ) under the influence of certain conditions like temperature, $\mathrm{pH}$, carbon source, and moisture. Thus, this review will focus on discussing the different approaches of bioremediation and phytoremediation using microorganisms and some plants respectively to safely maintain an eco-friendly environment. Both prokaryote and eukaryote that useful in environmental bioremediation are discussed in this review. They include but not limited to bacteria, yeast, algae, and fungi. Some plants that have exhibited similar characteristics are discussed as well. This review further addressed the different methods of detecting toxic metals in the environment. Understanding the mechanisms used by some microbes and plants to remediate environmental contaminants is still not clear and requires additional attention.
\end{abstract}

\section{Introduction}

Environmental pollution can occur naturally as a result of volcanic eruption, radioactivity, wildland fire, or even dust from storms [1]. Rainfall can increase the runoff of some of the contaminants into the aquatic system [2-4]. However, human activities such as industrialization like mining, urbanization, and excessive use of fertilizers are mostly an integrate contributor to environmental pollution [2,5]. Gavrilescu in 2010 reported that due to increasing demands and developments, pollution in air, soil and water has amplified leading to increased air pollution $\left(\mathrm{CO}_{2}\right.$ and hazardous chemical), water pollution (petroleum oil spill and many biological pollutants), and as well as chemical waste in soils [6]. Several chemical compounds have been identified as major causes of environmental pollution, some of which include iron (Fe), lead $(\mathrm{Pb})$, tin (Sn), manganese (Mn), zinc (Zn), mercury ( $\mathrm{Hg})$, copper (Cu), cadmium (Cd), calcium (Ca), silver (Ag), a variety of hydrocarbons from crude oil, and many more [1]. Clean-up of these heavy metals can be an extremely tedious and expensive; in some case, damage is irreversible, thereby interfering with the environmental quality and overall health of humans and animals [7-9].

Nonpathogenic microbes play a vital role in recycling of waste products [10]. Some of their activities include degrading organic materials and recycling nutrients in the soil [10], biodegradation, wastewater treatment process, and creating alternative energy. Microorganisms can degrade household wastes and human wastes 
through different mechanisms, which include the production of energy through the detoxification of harmful pollutants [11]. Different naturally occurring microbes in deep waters can consume hydrocarbon to facilitate the clean-up process of oil spills $[12,13]$ by breaking down the ring structures of hydrocarbons using some enzymes [12]. This method has been demonstrated through the use of bioleaching [14], which involves bio-oxidation of complex metals. Use of microorganisms to control the leachability of toxic metals has been favored over the physio-chemical process in recent times [15]. However, improper disposal of hazardous waste after clean-up can contribute to their release in the environment [12].

Despite several advances made to detect and analyze disposal of toxic chemicals, a wide range of undetected contaminants raises environmental concern [16]. Environmental contaminants can remain mobile or stationary from the point of contamination. The biggest hurdle is that no detailed pathway on how these emerging pollutants interact with the environment $[17,18]$. Human activities also play a key role in accumulating emerging pollutants such as global accumulation of $\mathrm{Hg}$ [19]. To address these challenges, biotechnology has been used to increase the likelihood of efficient recovery and detection of heavy metals in the environment $[6,15,20,21]$. Also, the field of molecular biology and nanotechnology have contributed towards a better understanding of the role's microorganisms play in the remediation of environmental pollution [22]. This is because of their catalytic, and reusable features [23]. This unique characteristic further distinguishes the use of biotechnology over the conventional physio-chemical method because they are very efficient in environmental conservation.

Different methods such as physical, chemical and biological processes have been researched, developed and used to reduce, transform and immobilize such environmental pollutants over the years. However, each of the methods has advantages and disadvantages. This review will evaluate the different sources of environmental contaminations, addressing the different strategies of bioremediation, and identify possible indicators for monitoring environmental pollution in an economical and eco-friendly approach.

\section{Biochemical Source of Pollution}

Some microorganisms are beneficial towards an efficient bioremediation strategy [22], but at the same time, some can contribute towards an increased pollution due to their metabolic activities in the case $\mathrm{Hg}$ transformation and methylation [24-26]. Microbes that were not previously considered as part of traditional contaminants or known to aid in contamination can now be identified from areas of pollution due to evolution of new techniques [6], thanks to the recent advances in biotechnology. The new strains can be attributed to some resistance genes obtained by some of the microbes due to prolonged exposure of contaminants [27]. Owing to their resistance and genetic modification, identification of such microbes does not follow the conventional method of microbial isolation.

Biochemical accumulation of biological substances from viruses and bacteria (Micropollutants) known to cause emerging and re-emerging waterborne pathogens [27] can be very difficult to remove especially in the water system. Micropollutants are a result of various activities of microbial processes because of prolonged accumulation in the environment either by natural or human activities [27]. On the other hand, increase in the chemical waste can aid metabolites of micropollutants over the time, thereby increasing the likelihood of biological pollution [27].

As mentioned earlier, agricultural practice can also intensify this process $[1,16,28,29]$. Introduction of fertilizers and pesticides into soils can cause health challenges when the chemicals leach off into nearby surface and groundwater [30]. Thus, detection of pesticides in groundwater around the world has become more common [3]. Although some microorganisms contribute to the detection of micropollutants within a water source, its mechanism is yet unknown [31]. Micropollutants are more abundant in Wastewater Treatment Plants (WWTP) compared to other sources of contaminations [31]. Introduction of micropollutants from WWTP to the landfill stays on the increase because of inadequate understanding of some harmful contributions that micropollutants causes. However, the efficiency of removing micropollutants from effluents by WWTPs depends upon the concentration of the pollutants and how efficient the treatment plant is towards the removal of such waste [27].

There have been greater numbers of antibiotics detected in effluents compared to other drugs and cosmetics flooding the sewer system from households; however, only an average of $51.4 \%$ of them are usually removed [27]. Also, removal of chemical contaminants like steroids, or detergents is dependent on its structural stability, bioavailability, and biodegradability of such compound [27]. Different bacteria and viruses like phages have been employed for the detection of pollutants from WWTPs. Biological pollutants possess greater risk but can be controlled with a cost-efficient process using advanced technologies [3,4]. Although treatment of most pollutants requires the aid of some specific microorganisms, interdisciplinary approaches can also increase its efficiency.

\section{Strategies for Bioremediation}

An aspect of biotechnology that is rapidly growing is environmental bioremediation $[12,15,32,33]$. Bioremediation is an emerging area focused on addressing different aspects of environmental pollution using microbes and plants occurring naturally in an eco-friendly, and cost-efficient way [15]. Bioremediation can be divided into four distinct categories: removal, separation, degradation, and immobilization [34-36], to eliminate or reduce the pollutants through physical, biological, or chemical process [31]. Immobilization can occur naturally owing to the availability of optimum condition. For bioremediation to be considered successful, pollutants must be converted to harmless by-products by either microorganisms or plants. Bioremediation can be mitigated either within the contaminated site (in situ) or total transfer of a contaminant to a different location (ex situ) [37]. In-situ is less expensive, less technical and most preferred compared to ex-situ during an environmental restoration [16]. 
One important aspect of bioremediation is genetic modification, which broadens the ability of microbes to target a vast range of contaminants under a defined condition $[3,6,9,5]$. This is through the application of genetic and enzymatic strategies to enhance energy development and utilization $[1,20,38]$. Bacteria like Bacillus thuringensis, widely known to break hydrocarbons from oil spills, were successfully modified to detoxify and consume radioactive waste [12]. Plants have also been successfully modified to increase their ability to absorb toxic chemicals compared to wild types [29,39-43].

Another aspect is the combined actions of different microbes identified from a contaminated site [31]. This technology was used to reduce the cost of cleaning oil spills from landfills thereby improving an approach that favors the environment in a fast and efficient manner [21]. The results obtained showed that using different microbial groups improves the biodegradation of oil contamination, and they also helped in restoring the soil to its natural and fertile state [21]. The synergy identified among different microorganisms can be attributed to shared enzymatic activities that make it easy to effectively degrade oil and waxy substances.

Of all the discussed advantages of bioremediation, it is important to acknowledge that some chemical substances can resist remediation through the different methods described, and some microbes require specialized nutrient for their growth making it difficult to inoculate them in the environment [22]. Microbes may not efficiently metabolize pollutants and become environmentally problematic during the clean-up process resulting in reintroduction of the contaminant back into the environment [31]. The interaction between microbes and plants can limit the effective removal of toxic chemicals [44]. For example, due to the heterogeneous nature of microbes in the environment interaction and dependency can be limited thereby destabilizing microbial effectiveness. Overall, some abiotic factors that can contribute to such limitations as stated above include $\mathrm{pH}$, temperature, electron and carbon exchange, enzymatic activities, and diversity among the population.

The surface area of contamination is also a determining factor towards a successful bioremediation [31]. For example, during phytoremediation, the roots of the plants shown to be very important in absorbing contaminants [44]. This can help accelerate or negatively impact the degradation ability of the plant. Increase in the surface area covered by contaminant can result in a less effective or more costly remediation process. In other words, the size of the plant becomes a deciding factor towards an effective phytoremediation. Bioremediation has not been well studied and as such is considered an emerging technology that is very promising in removing environmental contaminants like toxic chemicals from the environment [27]. Biotechnology presents a clear understanding of the biotic and abiotic approach towards environmental remediation. This includes biodegradation of pollutants using microorganisms or biological agents such as enzymes $[1,15,20,38,45]$. Biotechnology is comprised of promising techniques in environmental microbiology that have been proven to increase the efficiency of bioremediation through the use of intracellular and extracellular enzymes [46]. For better clarity, we discussed bioremediation in regard to bacteria, yeast, micro-algae, fungi, and plants.

\section{Bacteria}

Bacteria can remove heavy metals like Hg through the adsorption and combination of available amino or carboxyl groups present on the cell wall [10]. Their role in detoxification and biodegradation of toxicants has been well demonstrated. Such transforming ability was exhibited in Chiarella vulgaris and Zoogloea ramigera [47]. Gram-positive bacteria, owing to their tick cell wall have been shown to have a great ability to absorb heavy metals. Most of these gram-positive bacteria, Actinomycetes, Azotobacter and Pseudomonas have been shown to synthesize metals like Fe (II) as part of their normal metabolism [48]. As a beneficial process, they use this metal as their source of energy. Because they spend Fe (II) as part of their metabolic activities, such metal can be efficiently recycled from the environment [48].

Another promising area that bacteria have been applied to widely is in hydrocarbon degradation [21,49]. This has been demonstrated through the breaking of complex hydrocarbon molecules by Pseudomonas considered to be "fuel consuming" bacteria [50]. A special strain of Pseudomonas, P. syringae can even accumulate metals like $\mathrm{Ca} 2+, \mathrm{Mn} 3+, \mathrm{Cd} 2+, \mathrm{Zn} 2+, \mathrm{Cu} 2+$, and $\mathrm{Hg} 2+$, while Fe (III) reducing Geobacter matallireducens can also oxidize aromatic hydrocarbons like benzene [51]. The synergetic effect of Acinetobacter calcoaceticus and Alcaligenes odorans, and other tropical soil isolates of Serratia marcescens is effective in removing and breaking hydrocarbons within two weeks [13,49].

Other forms of contamination that are mostly encountered because of agricultural activities are pesticides. Pesticides are great contaminator of the aquatic system, killing most of its habitats like fish and eventually humans [17,30]. Other chemicals can also contaminate the aquatic system through other processes, which may lead to neurotoxicity. Some pesticides used for agricultural purposes include $\alpha$-endosulfan and $\beta$-endosulfan. They were efficiently degraded by Pseudomonas sp. and Arthrobacter sp. as short as one week [52]. However, it was reported that increasing concentration of chlorpyrifos above $50 \mathrm{mg} / \mathrm{L}$ can inhibit the effectiveness of Pseudomonas aeruginosa [53]. This demonstrates that factors like chemical concentration can influence the efficiency of bacteria to remediate compounds like pesticide efficiently. Some of the bacteria involved in bioremediation are summarized on Table 1.

\section{Yeast}

Another aspect of bioremediation that has received attention is the use of yeast to remediate environmental pollutants. Yeasts are known to withstand unfavorable environmental conditions, making them ideal for bioremediation [13,54]. Most yeasts are catalytically and structurally functional in decolorizing dye produced in effluents from food and textile industries [55] through extracellular absorption and adsorption [56]. Species of yeasts that have been recorded to be vital towards bioremediation are summarized on Table 1, and they include Pichia, Rhodosporidium, 
Leucosporidium, Rhodotorula, Sporidiobolus, Sporobolomyces, Trichosporon, Yarrowia, Stephanoascus, Clavispora, Candida and Debaryomyces [57]. Candida has a special characteristic to be environmentally susceptible to harsh conditions. Candida utilis has demonstrated the ability to accumulate radionuclides and shown to remove cadmium in its soluble form [58]. Furthermore, Canida can breakdown hydrocarbons from a crude oil spill in a short period. Candida tropicalis isolated from tropical soil was shown to effectively remove hydrocarbons from oil spill for as short as two weeks [13]. Some other spices of yeast like Rhodotorula mucilaginosa and Pichia guilliermondii have also demonstrated the adsorption and uptake ability of other heavy metals like silver, and chromium (III and VI) [59].

Table 1: Different microorganisms proven to treat various environmental contaminants.

\begin{tabular}{|c|c|c|c|c|c|c|}
\hline Category & Contaminant & Group & Family/genus & Species & Interaction & References \\
\hline \multirow{9}{*}{ Bacteria } & Heavy metals & $\begin{array}{c}\mathrm{Hg}, \mathrm{Ca}, \mathrm{Cr}, \\
\mathrm{Mn}, \mathrm{Cu}, \mathrm{Cd} \text {, and } \mathrm{Zn}\end{array}$ & $\begin{array}{l}\text { Pseudomonas } \\
\text { Serratia }\end{array}$ & $\begin{array}{l}\text { Syringae } \\
\text { marcescens }\end{array}$ & Independent & {$[49,51]$} \\
\hline & $\begin{array}{c}\text { Radioactive } \\
\text { waste }\end{array}$ & & Bacillus & Thuringensis & Independent & [12] \\
\hline & \multirow{5}{*}{$\begin{array}{c}\text { Aromatic } \\
\text { Hydrocarbons }\end{array}$} & \multirow{5}{*}{ Oil spill } & Geobacter & Matallireducens & Independent & {$[51]$} \\
\hline & & & Acinetobacter & Calcoaceticus & Synergetic & {$[13,49]$} \\
\hline & & & Alcaligenes & odorans & & \\
\hline & & & Serratia & marcescens & & \\
\hline & & & Candida & tropicalis & & \\
\hline & \multirow{2}{*}{ Pesticides } & \multirow{2}{*}{$\begin{array}{c}\text { a-endosulfan, } \\
\text { and b-endosulfan }\end{array}$} & Pseudomonas & Aeruginosa & Synergetic & {$[52,53]$} \\
\hline & & & Arthrobacter & $S p$ & & \\
\hline \multirow{3}{*}{ Yeast } & \multirow{3}{*}{ Heavy metals } & \multirow{3}{*}{$\begin{array}{c}\mathrm{Ca} \\
\mathrm{Ag} \text { and } \mathrm{Cr}\end{array}$} & Candida & utilis & Independent & [58] \\
\hline & & & Rhodotorula & mucilaginosa & Synergy & [59] \\
\hline & & & Pichia & guilliermondii & & \\
\hline Algae & $\begin{array}{l}\text { Diary industries } \\
\text { and waste } \\
\text { treatment plants }\end{array}$ & & Aphanocapsa & $S p$ & & \\
\hline & & & Oscillatoria & salina & Independent & [64-67] \\
\hline & & & Plectonema & terebrans & & \\
\hline & & & Synechococcus & $S p$ & & \\
\hline & & & Anabaena & inaequalis & & \\
\hline & & & Chlorella & $S p$ & & \\
\hline & & & Stigeoclonium & tenue & & \\
\hline & & & westiellopsis & prolifica & & \\
\hline \multirow{10}{*}{ Fungi } & \multirow{4}{*}{$\begin{array}{c}\text { Xenobiotic } \\
\text { degradation } \\
\text { Lignin from wood } \\
\text { debries }\end{array}$} & & Polyporus & Sp. & Synergetic & {$[33,71]$} \\
\hline & & & Phanaerochaete & chrysosporium & & \\
\hline & & & Cyathus & Bulleri & Synergetic & {$[72]$} \\
\hline & & & Phanaerochaete & chrysosporium & & \\
\hline & \multirow{2}{*}{$\begin{array}{c}\text { Diesel waste } \\
\text { in soil Aromatic }\end{array}$} & \multirow{2}{*}{ Polycyclic } & Pleurotus & Ostreanus & Independent & [73] \\
\hline & & & Stenotrophomonas & Maltophilia & Synergetic & {$[74]$} \\
\hline & Hydrocarbon & & Penicillium & janthinellum & & \\
\hline & \multirow{3}{*}{ Heavy metal } & $\mathrm{Cu}[\mathrm{II}], \mathrm{Cd}[\mathrm{II}]$ & Escherichia & coli & Synergetic & {$[60,75]$} \\
\hline & & & Bacillus & subtilis & & \\
\hline & & $\begin{array}{c}\text { dichlorophenol, } \\
\text { Ametryn, and } \\
\text { Acephate }\end{array}$ & Saccharomyces & cerevisiae & & \\
\hline \multirow[t]{2}{*}{ Green Plants } & $\begin{array}{l}\text { Heavy metals on } \\
\text { plant roots }\end{array}$ & $\begin{array}{c}\mathrm{Cd} \text { and } \mathrm{Zn}, \mathrm{Cu}, \mathrm{Pb}, \mathrm{Ni} \text {, } \\
\text { and } \mathrm{Cr}\end{array}$ & Salix & viminlais & Independent & {$[40]$} \\
\hline & $\begin{array}{l}\text { Heavy metals on } \\
\text { plant leaves }\end{array}$ & $\mathrm{Pb}, \mathrm{Ni}$, and $\mathrm{Co}$ & Pteridium & esculentum & Independent & [79] \\
\hline
\end{tabular}


As mentioned earlier, availability of essential nutrients can improve the rate at which microorganism absorb toxic pollutants. In the presence of riboflavin, the ability of Pichia sp. to resist chromium increases compared to when riboflavin is limited [54]. There was no explanation of how and why this happens. The need for a more interdisciplinary approach is very important to fully understand the best way to optimize this promising area of environmental bioremediation.

\section{Phycoremediation}

Phycoremediation is the use of micro-algae for the removal or toxicity reduction of biotransformable pollutants from the environment [11]. Phycoremediation is very wide-ranged because of the ability of algae to withstand harsh environmental conditions [12]. Algae can grow independently or dependently in the environment, most especially in the deep-sea horizon like oceans and lakes [11]. Algae are mostly primitive photosynthetic multicellular organisms with chlorophyll; however, they lack true characteristics of terrestrial plant such as true leaves, stems and roots. One of the ways that make algae environmentally important in the aquatic system is their ability to reduce the Biological Oxygen Demand (BOD), adjustment of $\mathrm{pH}$ to a safer form, and remove toxic metals from sludge [60]. Reduced BOD level can be achieved through the metabolic process of algae to make more $\mathrm{O}_{2}$ by fixing $\mathrm{CO}_{2}$, thereby making the aquatic system bio-stable [11]. Algae can control environmental contaminants through the intracellular accumulation of heavy metals and organic pollutants; they can also cycle nitrogen to a more useful form [61]. The most likely mechanism that explains how algae detoxify toxic metals involves physical adsorption, subsequently transported into the cytoplasm through a process described as chemisorption and finally intracellular uptake [62]. Algae play an important role in the removal of toxic contaminants from the aquatic environment. They have also been considered as a multifunctional polymer because of their ability to sequester toxic metals within their cell wall. These processes and more are widely applied in textile industries and mostly WWTP [55,63].

Cyanobacteria and blue-green algae have been shown to be economical and can withstand extreme environmental conditions ranging from salinity, temperature and nutritional composition [12]. Species like Aphanocapsa sp., Oscillatoria salina, plectonema terebrans, Synechococcus sp., Anabaena inaequalis, Chlorella sp., Stigeoclonium tenue, and Westiellopsis prolifica has been used as a bioremediating agent in dairy industries, water treatment plants, and industrial effluents like oil spill removing over $75 \%$ of toxic wastes [64-67]. While algae are naturally occurring and removal of pollutants occur concurrently as part of their normal metabolic activities some algae are expected to be more effective than others. This feature makes application of algae that are more susceptible to harsh environmental condition suitable and inexpensive method to safely remediate environmental pollutants compared to other physical remediation processes. Some of the algae involved in bioremediation are summarized in Table 1.

\section{Mycoremediation}

Mycoremediation involves the effective use of mycelium from fungi to bioremediate toxic environmental chemicals. The surface ratio of the fungal cell is very important in its ability to withstand the high concentration of toxic chemicals through mechanical and enzymatic activities when in contact with the environment $[68,69]$. This may not be possible if the toxic compounds are directly introduced into the cells. Unlike phycoremediation, mycoremediation is more effective with acids and extracellular enzymes produced from fungal mycelia that can breakdown cellulose [12]. Some other factors like organic acid, chelators, and flexible $\mathrm{pH}$ also contribute towards the process of bioremediation by fungi [70]. The key challenge with this process is the identification of suitable fungi that can produce such enzymes.

Some of such fungi that have been identified to be an ideal model to understand xenobiotic degradation are summarized in Table 1. They include Polyporus sp., and Phanaerochaete chrysosporium, with the help of the enzymes that they produced [33,71]. Apart from degrading complex carbons, Synergetic action of Cyathus bulleri and enzymes secreted by Phanaerochaete chrysosporium can be used to degrade lignin from debries of woods [72]. Pleurotus ostreanus detoxified up to $95 \%$ of diesel contaminated soil within four weeks by using its mycelial [73]. The results from the study suggested that the ability of fungi to degrade toxic pollutants lies between the interaction of its intracellular and extracellular enzymes [73]; however, such report is yet inconclusive as there is no strong evidence supporting such claims. In other words, a more biochemical analysis is needed to better understand the full mechanism of how this process works in other to fully utilize the bioremediation potentials of most fungi.

Also, fungal genes that code for degenerative enzymes as described above can be cloned into bacteria for an effective result. Fungi can even be genetically modified to thrive better in a broad range of environmental contaminant. Another alternative is to coculture fungi with bacteria since we know that pure culture can hardly be obtained in the environment. The benefit of co-culture between bacteria and fungi was described using Stenotrophomonas maltophilia and Penicillium janthinellum respectively to degrade polycyclic aromatic hydrocarbons effectively compared to when tested independently [74]. Combination of gram-negative bacteria (Escherichia. coli), gram-positive bacteria (Bacillus subtilis), and fungus (Saccharomyces cerevisiae) at a specific ratio 2:2:1 showed great specificity against $\mathrm{Cu}$ (II), Cd (II), 3,5- dichlorophenol, Ametryn, and Acephate [75]. The synergetic effect above showed significant sensitivity when the bacteria and fungi formed balanced association. Developing a more detailed association between fungi and bacteria can help improve identification and recovery of contaminated ecological habitats.

\section{Phytoremediation}

Phytoremediation is a low-cost remediation method that uses a specific green plant to remove environmental contaminants 
from soil, sludge, sediment, surface and groundwater, and air insitu[39,76]. It is a fast and environmentally friendly way of removing contaminants, thereby preserving the properties of the soil without adjusting its chemical composition and maintaining the microbial biomass [77]. Most of the plants involved in remediation are categorized either as hyperaccumulator or non-hyperaccumulator [29]. Hyperaccumulator does not require any supplemental metalloenzymes chelated for its efficiency to take up heavy metals compared to non-hyperaccumulator that require such. Some of the plants identified to be hyperaccumulator of pollutants include Astragalus racemosus, Haumaniastrum robertii, Ipomea alpine, Thlaspi caerulescens and Sebertia acuminate [29].

There are different mechanisms that have been proposed to be involved with phytoremediation [40]. First, is phytoextraction, this is a process that involves the direct uptake and degradation of organic pollutants within the plant's? vacuole and second, with enzymes (laccase, nitrilase, dehalogenase, and nitroreductase) or through another process known as rhizoremediation that involves the use of modified microbes within the rhizosphere that can be integrated into the soil or water $[43,44,96]$. Salix viminlais and Pteridium esculentum are good examples of rhizofiltration and phytoextractor respectively. Salix viminlais was shown to concentrate heavy metals from the root to the shoot of the plant and Pteridium esculentum was able to accumulate heavy metals in the leaves of the plant $[40,79]$. This process is very reliable in cleaning up environmental contamination at a much faster rate. Another mechanism involves the removal of metals bound to the soil through the help of specific plasma membrane such as metal reductase from the roots to acidify the toxic metals $[80,81]$. Some of the green plants involved in remediation are summarized on Table 1.

The presence of enzymes produced by plants during phytoremediation also increases the ability of microorganisms that are present in the rhizosphere to degrade other pollutants [78,82], and increase the bioavailability of metals [42]. This process helps to increase co-metabolism and as well improve the rate at which pollutants are removed through the combined effort of both microorganisms and plant. Another important note is that harvested plants that have been used to remediate toxic metals can be properly recycled without introducing other chemical complexity in the environment [43]. Constant circulation of rhizofiltration increases its ability to breakdown toxic metals without interfering with the environment; this attribute might make it more advantageous over phytoextraction.

\section{Biological Indicators/Monitors}

With increased health challenges, due to rapid environmental contamination, the need for rapid indicators that can detect the presence of contaminants in the environment is very important. Bioindicators are biological species that can exist as single species or in communities to help evaluate the quality and change of an environment over time [83]. Although microbial communities can make good indicators of environmental change, changes to the community due to other environmental factors can influence the authenticity of the result obtained [83]. Single species can also become too sensitive to environmental conditions, thereby making it difficult to depend on its result. Some few examples of bioindicators are algae (Chlorella ellipsoidea), macrophyte (Fontinalis antipyretica), crustacean (Daphnia magna), insects (Ischnura elegans), gastropod (Cipangopaludina cahayenisis), fish (zebrafish), amphibian, nematodes, and plants [84,85]. Fishes like Cutthroat trout and Oreochromis niloticus have been used to detect changes in water temperature over time $[83,86]$, because they are very sensitive to high temperature. Their heat shock gene can be used to detect thermal stress. Moss (Hylocomium splendens) was used in northwestern Alaska to estimate the influence of overland transport of heavy metals on surrounding terrestrial biota [87]. An integrated biological response has been used to stimulate a more effective biomonitoring system towards desired operational goals and provide more practical information.

There is a broad difference between bioindicators and biomonitors, bioindicators are qualitative while biomonitors are quantitative $[1,83]$. Bioindicators are used to access biotic response due to environmental stress, while biomonitoring is used to identify the severity of pollution. Some of the biomonitoring approaches include evaluation of biota population, use of bacteria to test for acute toxicity, and residual analysis. For example, the use of bioluminescent bacteria can help in the detection of organic and inorganic pollutants $[20,88]$. This approach deals with genetically modified bacteria that emit light. Luminescent organisms were used to detect pollutants in wastewater, seawater, surface and groundwater, soil and sediments, and air as a biomonitor [20], they are very sensitive, fast and accurate because of their affinity with chemical contaminants. Plants can also be beneficial in monitoring environmental contamination like identical perennial shrub Rosa rugose [89]. It was successfully used to monitor the accumulation of heavy metals like lead in different areas over time.

Although the concentration of contaminants can occur at a very low rate, bioindicators have shown to be a suitable technique for the detection of such contaminant. So many other contaminations occur because of indirect pollution. For example, a sewage pipe releasing nitrate into an aquatic system can alter the ecological balance of the aqua system. Therefore, an increase in some species that solely use nitrate can indicate an unusual increase in nitrate. This is very applicable since the main goal when using bioindicator is to use single sensitive species or group of species to evaluate the changes happening within a complex environment over time $[75,83]$.

\section{Indicators of Environmental Pollution}

Natural occurring microorganisms or plants can degrade an environmental pollutant as part of their normal metabolism or as part of a process known as co-metabolism [90,91]. Co- metabolism is the mutual degradation of a compound due to the combined effort of different microorganisms trying to metabolize natural occurring elements vital to their natural metabolism biochemically [90-93], in return, they may increase the toxicity of such compound. Cometabolism can also be described as the use of energy obtained from oxidation? process to maintain microbial growth [94]. One example 
of such activity is the methylation of Hg. Mercury methylation is increased in the presence of augmented natural organic matter compared to when reduced [95]. Also, in the presence of $\mathrm{Zn}$, Dunalliela tertiolecta can become more tolerant towards other heavy metals like $\mathrm{Hg}, \mathrm{Pb}, \mathrm{Cu}$, and $\mathrm{Cd}$ [96]. Biodegradable organic matter can easily be manipulated using either aerobic or anaerobic microbes. However, it has been suggested that due to possible microbial degradation, aerobic organisms favor bioremediation more when compared to anaerobic organisms [97].

Bacteria like Bacillus, Pseudomonas, and Streptomyces have been used to demonstrate the ability of bacteria to be effective biosorption tools against pollutants (chromium (VI), lead (II), and hydrocarbons) both in sediments and in solution [50,98,99]. Because aerobic and anaerobic organisms degrade chemical compounds through different unique pathways such as oxidation, reduction and even through hydrolysis, a detailed understanding of selected organisms is important to adequately utilize the full benefit of such organism.

Several mechanisms are involved in the use of microbes to reduce environmental waste; however, no conclusive mechanism has been reported $[100,101]$. Some of these mechanisms include intracellular uptake, sorption, and extracellular accumulation $[63,102,103]$. These three steps are vital in accessing the different mechanisms that microbes use to detoxify metals. Some of the processes might require the use of live cells, the formation of complex chemical molecules on the cell membrane of the bacteria and precipitation of toxic chemicals to a less toxic form. Living cells are mostly involved in the intracellular accumulation and metabolism; however, intracellular accumulation pollutants can be facilitated in both living and dead cells $[10,104]$. Dead cells are most preferred because it is easy to clean-up after use and does not require additional nutrient to improve the biomass of the bacteria cells [69].

For a successful bioremediation using microorganisms, the environmental condition must be carefully monitored for favorable microbial growth $[3,7]$. The presence of adjacent nutrients can increase the robustness of microbial growth and impact bioremediation effectiveness [12]. This interaction can increase or decrease microbial effectiveness to breakdown toxic chemicals. For example, interaction between Ganoderma lucidum and Aspergillus niger demonstrated an effective ion exchange when inoculated together and as such increased the reduction of chromium [105]. Bioremediation involves much more microorganisms and plants than already demonstrated in the literature.

\section{Other Bioremediation Strategies}

There are different environmental clean-up processes such as the conventional physiochemical process, which removes the contaminants only from the point of contamination and introduces it to another uncontaminated site [31]; this can occur during transport of the contaminant to the disposal site. Techniques like this can be very expensive, and in some cases the pollutant will not be detoxified, this method leaves a vast health and environmental concern when the contaminant is not properly handled [19]. The second method is the use of Ultra-Violet (UV) radiation, which is very expensive. Regardless of the ability to use UV oxidation to remove contaminants like inorganic hydrocarbons, continued exposure to UV can be very detrimental to health [32]. However, these limitations and more can be addressed through the help of emerging technology. Processes of biotechnology can inactivate environmental contaminants and transform them to a more biodegradable form that is practical, and safe without causing more damage and harm to the environment $[50,52]$.

\section{Summary/Discussion}

There has been a wide use of the word "green" to describe effective environmental restoration such as bioremediation; however, most of the effective bioremediation strategies do not necessarily use a "green" approach. Application of bioremediation involves both green (plant) and non-green (microorganism) approaches. The use of microorganisms to remove toxic chemicals was found to be very safe and efficient because they can use the chemical compounds as a carbon source and then convert them to a less toxic form. This process was shown to be possible through an enzymatically attack or intracellular metabolism of such toxic compound. To better understand the suitable approach of bioremediation, the question where and how the method will be used must be answered to address whether an in situ or ex-situ method will be necessary. Although there are several strategies or applications of bioremediation as discussed in this review, a better understanding of the mechanism involved will increase the effective application of this emerging area of biotechnology. Also, uniformity of methodology must be adopted for proper reliability and reproducibility. This will help improve each approach for a better application.

Different enzymes play different roles during bioremediation to humidify, oxidize and transform different phenolic aromatic substances by some bacteria that are present in the soil. Enzymes like oxidoreductase, oxygenase, monooxygenase, dioxygenase, and laccase have been used by bacteria, insects, fungi and plants to degrade phenolic and aromatic compounds [38]. Bacteria that secrete an enzyme can be modified or incorporated into a higher system like yeast with a different enzymatic activity to detoxify a wide range of toxic chemicals in the environment. This can help improve an early detection of environmental contamination before it spreads beyond control, when a close and continual monitoring is applied with the help of microorganisms and some plants.

Some other areas that need to be tapped into include the area of biomonitoring and bioidentification. This approach can be possible with the help of genetic sensing. Use of genetically modified microbes can improve the degradation of pollutants from soil, air, water and even industrial effluents. This is another emerging area of ecotoxicology that can be very helpful in detecting the abundance of different contaminants using microorganisms. Understanding the broad array of microbial abundance can help estimate the likelihood of contamination and can be a big step forward towards enhanced ecological risk assessment. This could open a new era 
that could perhaps remediate chemical wastes within its early stage before it spreads beyond control since the distribution rate of contaminants is essential for an effective remediation. A broader understanding of how bacteria and other naturally occurring species such as? fungi and plants can be used to produce a more efficient result in both biomonitoring and bioremediation will be a breakthrough.

\section{Acknowledgment}

The authors are very grateful to NSF-AGEP grant No. 1432991, DOE-SRNS grant No. 0000332981, and Alabama State University.

\section{References}

1. Zhou Q Zhang J, Fu J, Shi J, Jiang G (2008) Biomonitoring: An appealing tool for assessment of metal pollution in the aquatic ecosystem. Anal Chim Acta 606(2): 135-150.

2. Jördening HJ, Winter J (2006) Environmental biotechnology: Concepts and applications. John Wiley \& Sons pp. 488.

3. Cieślik BM, Namieśnik J, Konieczka P (2015) Review of sewage sludge management: Standards, regulations and analytical methods. J Clean Prod 90: 1-15.

4. Roig N, Sierra J, Martí E, Nadal M, Schuhmacher M, et al. (2012) Longterm amendment of Spanish soils with sewage sludge: Effects on soil functioning. Agric Ecosyst Environ 158: 41-48.

5. Liu H, Probst A, Liao B (2005) Metal contamination of soils and crops affected by the Chenzhou lead/zinc mine spill (Hunan, China). Sci Total Environ 339(1-3): 153-166.

6. Gavrilescu M (2010) Environmental biotechnology: Achievements, opportunities and challenges. Dyn Biochem Process Biotechnol Mol Biol $4: 1-36$.

7. Hough RL, Breward N, Young SD, Crout NMJ, Tye AM, et al. (2004) Assessing potential risk of heavy metal exposure from consumption of home-produced vegetables by urban populations. Environ Health Perspect 112(2): 215-221.

8. Nabulo G, Young SD, Black CR (2010) Assessing risk to human health from tropical leafy vegetables grown on contaminated urban soils. Sci Total Environ 408(22): 5338-5351.

9. Wang Q Dong Y, Cui Y, Liu X (2001) Instances of soil and crop heavy metal contamination in China. Soil Sediment Contam 10(1): 497-510.

10. François F, Lombard C, Guigner JM, Soreau P, Brian-Jaisson F, et al (2012) Isolation and characterization of environmental bacteria capable of extracellular biosorption of mercury. Appl Environ Microbiol 78(4): 1097-1106.

11. Fathi AA, Azooz MM, Al-Fredan MA (2013) Phycoremediation and the potential of sustainable algal biofuel production using wastewater. Am J Appl Sci 10: 189-194.

12. Bhatnagar S, Kumari R (2013) Bioremediation: A sustainable tool for environmental management -A Review. Annu Rev Res Biol 3: 974-993.

13. Ijah UJ J (1998) Studies on relative capabilities of bacterial and yeast isolates from tropical soil in degrading crude oil. Waste Manag 18: 293299.

14. Olson GJ, Brierley JA, Brierley CL (2003) Bioleaching review part B: progress in bioleaching: Applications of microbial processes by the minerals industries. Appl Microbiol Biotechnol 63(3): 249-257.

15. Singh R, Singh P, Sharma R (2014) Microorganism as a tool of bioremediation technology for cleaning environment: A review. Proc Int Acad Ecol Environ Sci 4(1): 1-6.

16. Nayfach S, Pollard KS, Parks JM, Johs A, Podar M, et al. (2013) Global prevalence and distribution of genes and microorganisms involved in mercury methylation. Appl Environ Microbiol 6: 1-8.
17. Stuart M, Lapworth D, Crane E, Hart A (2012) Review of risk from potential emerging contaminants in UK groundwater. Sci Total Environ 416: 1-21.

18. Pal A, Gin KYH, Lin AYC, Reinhard M (2010) Impacts of emerging organic contaminants on freshwater resources: Review of recent occurrences, sources, fate and effects. Sci Total Environ 408(24): 6062-6069.

19. Brooks SC, Southworth GR (2011) History of mercury use and environmental contamination at the Oak Ridge Y-12 Plant. Environ Pollut 159: 219-228.

20. Kudryasheva N, Kratasyuk V, Esimbekova E, Vetrova E, Nemtseva E, et al. (1998) Development of bioluminescent bioindicators for analysis of environmental pollution. F Anal chemestry Technol 2: 277-280.

21. Okoh AI (2006) Biodegradation alternative in the cleanup of petroleum hydrocarbon pollutants. Biotechnol Mol Biol 1: 38-50.

22. Egbo TE, Dickson J0, Miller C, Johs A, Sanders CA, et al. (2017) Characterization, identification and seasonal evaluation of microbes in mercury contaminated soils. Front Sci Technol Eng Math 1(1): 15-26.

23. Gomez-Pastora J, Dominguez S, Bringas E, Rivero MJ, Ortiz I, et al. (2017) Review and perspectives on the use of Magnetic Nanophotocatalysts (MNPCs) in water treatment. Chem Eng J 310: 407-427.

24. Riqing Y (2011) Microbial mercury methylation and demethylation: Biogeochemical mechanisms and metagenomic perspectives in freshwater ecosystems. pp. 1-118.

25. Kerin EJ, Gilmour CC, Roden E, Suzuki MT, Coates JD, et al. (2006) Mercury methylation by dissimilatory iron-reducing bacteria. Appl Environ Microbiol 72(12): 7919-7921.

26. Gilmour CC, Henry EA, Mitchell R (1992) Sulfate stimulation of mercury methylation in freshwater sediments. Environ Sci Technol 26(11): 22812287.

27. Gavrilescu M, Demnerová K, Aamand J, Agathos S, Fava F (2015) Emerging pollutants in the environment: Present and future challenges in biomonitoring, ecological risks and bioremediation. N Biotechnol 32: 147-156.

28. Neher DA (2001) Role of nematodes in soil health and their use as indicators. J Nematol 33: 161-168.

29. Wuana RA, Okieimen FE (2010) Phytoremediation potential of maize (Zea mays L.). A Review. African Stud Popul Heal 6(4): 275-287.

30. Houtman CJ (2010) Emerging contaminants in surface waters and their relevance for the production of drinking water in Europe. J Integr Environ Sci 7(4).

31. lausen L, Arildskov NP, Larsen F, Aamand J, Albrechtsen HJ (2007) Degradation of the herbicide dichlobenil and its metabolite BAM in soils and subsurface sediments. J Contam Hydrol 89(3-4): 157-173.

32. Mary Kensa V (2011) Bioremediation - An overview. J Ind Pollut Control

33. Kristanti RA, Hadibarata T, Toyama T, Tanaka Y, Mori K (2011) Bioremediation of crude oil by white rot fungi Polyporus sp. S133. J Microbiol Biotechnol 21(9): 995-1000.

34. Khan FI, Husain T, Hejazi R (2004) An overview and analysis of site remediation technologies. J Environ Manage 71(2): 95-122.

35. Doble M, Kumar A (2005) Biotreatment of Industrial Effluents. Elsevier pp. 336.

36. Majone M, Verdini R, Aulenta F, Rossetti S, Tandoi V, et al. (2015) In situ groundwater and sediment bioremediation: Barriers and perspectives at European contaminated sites. N Biotechnol 32: 133-146.

37. Barathi S, Vasudevan N (2001) Utilization of petroleum hydrocarbons by Pseudomonas fluorescens isolated from a petroleum-contaminated soil. Environ Int 26(5-6): 413-416.

38. Karigar CS, Rao SS (2011) Role of microbial enzymes in the bioremediation of pollutants: A Review. Enzyme Res 2011: 1-11. 
39. Memon AR, Aktoprakligil D, Özdemir A, Vertii A (2001) Heavy metal accumulation and detoxification mechanisms in plants. Turk J Botany 25(3): 111-121.

40. Salt D, Blaylock M, Kumar N, Dushenkov V, Ensley B, et al. (1995) Phytoremediation: A novel strategy for the removal of toxic metals from the environment using plants. Nat Biotechnol 13(5): 468-474.

41. Alkorta I, Garbisu C (2001) Phytoremediation of organic contaminants in soils. Bioresour Technol 79(3): 273-276.

42. Raskin I, Smith RD, Salt DE (1997) Phytoremediation of metals: Using plants to remove pollutants from the environment. Curr Opin Biotechnol 8(2): 221-226.

43. Garbisu C, Alkorta I (2001) Phytoextraction: A cost-effective plant-based technology for the removal of metals from the environment. Bioresour Technol 77(3): 229-236.

44. Sung K, Corapcioglu MY, Drew MC (2004) Plant aided bioremediation in the vadose zone: Model development and applications. J Contam Hydro 73(1-4): 65-98.

45. Vera M, Schippers A, Sand W (2013) Progress in bioleaching: Fundamentals and mechanisms of bacterial metal sulfide oxidation-part A. Appl Microbiol Biotechnol 97(17): 7529-7541.

46. Van Dillewijn P, Caballero A, Paz JA, González-Pérez MM, Oliva JM, Ramos JL (2007) Bioremediation of 2,4,6-trinitrotoluene under field conditions. Environ Sci Technol 41(4): 1378-1383.

47. Mallick N (2004) Copper-induced oxidative stress in the chlorophycean microalga Chlorella vulgaris: response of the antioxidant system. J Plant Physiol 161: 591-597.

48. Pattus F, Abdallah MA (2000) Siderophores and iron-transport in microorganisms. J Chinese Chem Soc 47: 1-20.

49. Lal B, Khanna S (1996) Degradation of crude oil by Acinetobacter calcoaceticus and Alcaligenes odorans. J Appl Bacteriol 81(4): 355-362.

50. Jayashree R, Nithya SE, Prasanna PR, Krishnaraju M (2012) Biodegradation capability of bacterial species isolated from oil contaminated soil. 1: 140-143.

51. Lovley DR (1993) Dissimilatory metal reduction. Annu Rev Microbiol 47: $263-290$.

52. Kumar M, Lakshmi CV, Khanna S (2008) Biodegradation and bioremediation of endosulfan contaminated soil. Bioresour Technol 99(3): 3116-3122.

53. Fulekar MH, Geetha M (2008) Bioremediation of chlorpyrifos by Pseudomonas aeruginosa using scale up technique. Appl Biosci 12: 657660.

54. Ksheminska H, Jaglarz A, Fedorovych D, Babyak L, Yanovych D, et al (2003) Bioremediation of chromium by the yeast Pichia guilliermondii: Toxicity and accumulation of $\mathrm{Cr}$ (III) and $\mathrm{Cr}$ (VI) and the influence of riboflavin on Cr tolerance. Microbiol Res 158(1): 59-67.

55. Dönmez G (2002) Bioaccumulation of the reactive textile dyes by Candida tropicalis growing in molasses medium. Enzyme and Microbial Technology 30(3): 363-366.

56. Chatterjee S, Gupta D, Roy P, Chatterjee NC, Saha P, et al. (2011) Study of a lead tolerant yeast strain BUSCY1 (MTCC9315). African J Microbiol Res 5(30): 5362-5372.

57. Csutak O, Stoica I, Ghindea R, Tanase AM, Vassu T (2010) Insights on yeast bioremediation processes. Rom Biotechnol Lett 15(2).

58. Kujan P, Prell A, Šafár̆ H, Sobotka M, Řezanka T, et al. (2006) Use of the industrial yeast Candida utilis for cadmium sorption. Folia Microbiol (Praha) 51(4): 257-260.

59. Gomes NCM, Rosa CA, Pimentel PF, Mendonça-Hagler LCS (2002) Uptake of free and complexed silver ions by different strains of Rhodotorula mucilaginosa. Brazilian J Microbiol 33(1): 62-66.
60. Wuana RA, Okieimen FE, Gerhardt KE, Huang XD, Glick BR, et al. (2001) Mechanisms white rot fungi use to degrade pollutants. Sci Total Environ Second 41: 161-168.

61. Huq I, Bulbul A, Choudhury MS, Alam S, Kawai S (2005) Arsenic bioaccumulation in a green algae and its subsequent recycling in soils of Bangladesh. In Natural Arsenic in Groundwater: Occurrence, Remediation and Management. pp. 119-124.

62. Vymazal J (1984) Short-term uptake of heavy metals by periphyton algae. Hydrobiologia 119(3): 171-179.

63. Kulbat E, Olańczuk-Neyman K, Quant B, Geneja M, Haustein E (2003) Heavy metals removal in the mechanical-biological wastewater treatment plant "Wschód" in Gdańsk. Polish J Environ Stud 12(5): 635641.

64. Rahman MA, Soumya KK, Tripathi A, Sundaram S, Singh S, et al. (2011) Evaluation and sensitivity of cyanobacteria, Nostoc muscorum and Synechococcus PCC 7942 for heavy metals stress - A step toward biosensor. Toxicol Environ Chem 93: 1982-1990.

65. Nakajima A, Tsuruta T (2004) Competitive biosorption of thorium and uranium by Micrococcus luteus. J Radioanal Nucl Chem 260(1): 13-18.

66. Bajguz A (2011) Suppression of Chlorella vulgaris growth by cadmium, lead and copper stress and its restoration by endogenous brassinolide. Arch Environ Contam Toxicol 60: 406-416.

67. Agnihotri VK (2014) Anabaena flos-aquae. Crit Rev Environ Sci Technol 44: 1995-2037.

68. Hurst CJ, Crawford RL, Garland JL, Lipson DA (2002) Manual of environmental microbiology $\left(2^{\text {nd }}\right.$ edn). American Society for Microbiology Press.

69. Bishnoi NR, Garima A (2005) Fungus - An alternative for bioremediation of heavy metal containing wastewater: A review. J Sci Ind Res 64(2): 93100 .

70. Wu J, Yu HQ (2007) Biosorption of 2,4-dichlorophenol by immobilized white-rot fungus Phanerochaete chrysosporium from aqueous solutions. Bioresour Technol 98(2): 253-259.

71. Levin L, Viale A, Forchiassin A (2003) Degradation of organic pollutants by the white rot basidiomycete Trametes trogii. Int Biodeterior Biodegrad 52(1): 1-5.

72. Favero N, Costa P, Massimino ML (1991) In vitro uptake of cadmium by basidiomycetes Pleurotus ostreatus. Biotechnol Lett 13(10): 701-704.

73. Boonchan S, Britz ML, Stanley GA (2000) Degradation and mineralization of high- molecular-weight polycyclic aromatic hydrocarbons by defined fungal-bacterial cocultures. Appl Environ Microbiol 66(3): 1007-1019.

74. Gao G, Qian J, Fang D, Yu Y, Zhi J (2016) Development of a mediated whole cell-based electrochemical biosensor for joint toxicity assessment of multi-pollutants using a mixed microbial consortium. Anal Chim Acta 924: 21-28.

75. Henderson KL, Belden JB, Coats JR (2007) Mass balance of metolachlor in a grassed phytoremediation system. Environ Sci Technol 41(11): 4084-4089.

76. Huang XD, El-Alawi Y, Penrose DM, Glick BR, Greenberg BM (2004) A multi-process phytoremediation system for removal of polycyclic aromatic hydrocarbons from contaminated soils. Environ Pollut 130(3): 465-476.

77. Gerhardt KE, Huang XD, Glick BR, Greenberg BM (2009) Phytoremediation and rhizoremediation of organic soil contaminants: Potential and challenges. Plant Sci 176(1): 20-30.

78. Robinson B, Kim N, Marchetti M, Moni C, Schroeter L, et al. (2006) Arsenic hyperaccumulation by aquatic macrophytes in the Taupo Volcanic Zone, New Zealand. Environ Exp Bot 58(1-3): 206-215.

79. Welch RM, Norvell WA, Schaefer SC, Shaff JE, Kochian LV (1993) Induction of iron(III) and copper(II) reduction in pea (Pisum sativum 
L.) roots by Fe and Cu status: Does the root- cell plasmalemma Fe(III)chelate reductase perform a general role in regulating cation uptake? Planta 190(4): 555-561.

80. Crowley DE, Wang YC, Reid CPP, Szaniszlo PJ (1991) Mechanisms of iron acquisition from siderophores by microorganisms and plants. Plant Soil 130(1-2): 179-198.

81. Teng Y, Luo Y, Sun X, Tu C, Xu L, et al. (2010) Influence of arbuscular mycorrhiza and Rhizobium on phytoremediation by alfalfa of an agricultural soil contaminated with weathered PCBs: A field study. Int J Phytoremediation 12: 516-533.

82. HoltEA (2010) Bioindicators: using organisms to measure environmenta impacts. Nat Educ Knowl 3: 1-8.

83. Birungi Z, Masola B, Zaranyika MF, Naigaga I, Marshall B (2007) Active biomonitoring of trace heavy metals using fish (Oreochromis niloticus) as bioindicator species. The case of Nakivubo wetland along Lake Victoria. Phys Chem Earth 32: 1350-1358.

84. Hasselbach L, Ver Hoef JM, Ford J, Neitlich P, Crecelius E, et al. (2005) Spatial patterns of cadmium and lead deposition on and adjacent to National Park Service lands in the vicinity of Red Dog Mine, Alaska. Sci Total Environ 348: 211-230.

85. Girotti S, Ferri EN, Fumo MG, Maiolini E (2008) Monitoring of environmental pollutants by bioluminescent bacteria. Anal Chim Acta 608(1): 2-29.

86. Calzoni GL, Antognoni F, Pari E, Fonti P, Gnes A, et al. (2007) Active biomonitoring of heavy metal pollution using Rosa rugosa plants. Environ Pollut 149(2): 239-245.

87. Schaefer JK, Yagi J, Reinfelder JR, Cardona T, Ellickson KM, et al. (2004) Role of the bacterial organomercury lyase (MerB) in controlling methylmercury accumulation in mercury-contaminated natural waters. Environ Sci Technol 38(16): 4304-4311.

88. Schaefer JK, Szczuka A, Morel FM M (2014) Effect of divalent metals on Hg (II) uptake and methylation by bacteria. Environ Sci Technol 48(5): 3007-3013.

89. Morris BE L, Henneberger R, Huber H, Moissl-Eichinger C (2013) Microbial syntrophy: Interaction for the common good. FEMS Microbiol Rev 37(3): 384-406.

90. Dagley S (1987) Lessons from biodegradation. Annu Rev Microbiol 41: $1-24$

91. Horvath RS (1972) Microbial co-metabolism and the degradation of organic compounds in nature. Bacteriol Rev 36(2): 146-155.

92. Schaefer JK, Morel FM M (2009) High methylation rates of mercury bound to cysteine by Geobacter sulfurreducens. Nat Geosci 2: 123.

ISSN: 2574-1241

DOI: 10.26717/BJSTR.2019.13.002390

Timothy E Egbo. Biomed J Sci \& Tech Res

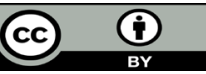

This work is licensed under Creative Commons Attribution 4.0 License

Submission Link: https://biomedres.us/submit-manuscript.php
93. Tsuji N, Hirayanagi N, Okada M, Miyasaka H, Hirata K, et al. (2002) Enhancement of tolerance to heavy metals and oxidative stress in Dunaliella tertiolecta by Zn-induced phytochelatin synthesis. Biochem Biophys Res Commun 293(1): 653-659.

94. Tor JM, Lovley DR (2001) Anaerobic degradation of aromatic compounds coupled to Fe(III) reduction by Ferroglobus placidus. Environ Microbiol 3(4): 281-287.

95. Gupta VK, Shrivastava AK, Jain N (2001) Biosorption of chromium(VI) from aqueous solutions by green algae Spirogyra species. Water Res 35 (17): 4079-4085

96. Selatnia A, Boukazoula A, Kechid N, Bakhti MZ, Chergui A, et al. (2004) Biosorption of lead (II) from aqueous solution by a bacterial dead Streptomyces rimosus biomass. Biochem Eng J 19(2): 127-135.

97. Gilmour CC, Podar M, Bullock AL, Graham AM, Brown SD, et al. (2013) Mercury methylation by novel microorganisms from new environments. Environ Sci Technol 47(20): 11810-11820.

98. Schaefer JK, Kronberg RM, Morel FM M, Skyllberg U (2014) Detection of a key $\mathrm{Hg}$ methylation gene, hgcA, in wetland soils. Environ Microbiol Rep 6(5): 441-447.

99. Kratochvil D, Volesky B (1998) Advances in the biosorption of heavy metals. Trends Biotechnol 16(7): 291-300

100. Kujan P, Prell A, Safár H, Sobotka M, Rezanka T, et al. (2005) Removal of copper ions from dilute solutions by Streptomyces noursei mycelium. Comparison with yeast biomass. Folia Microbiol (Praha) 50(4): 309313.

101. Dusane DH, Pawar VS, Nancharaiah YV, Venugopalan VP, Kumar AR, et al. (2011) Anti-biofilm potential of a glycolipid surfactant produced by a tropical marine strain of Serratia marcescens. Biofouling 27(6): 645-654.

102. Muraleedharan TR, Venkobachar C (1990) Mechanism of biosorption of copper(II) by Ganoderma iucidum. Biotechnol Bioeng 35(3): 320325.

103. Ahluwalia SS, Goyal D (2007) Microbial and plant derived biomass for removal of heavy metals from wastewater. Bioresour Technol 98(12): 2243-2257.

104. Lamborg CH, Fitzgerald WF, Damman AW H, Benoit JM, Balcom PH, et al. (2002) Modern and historic atmospheric mercury fluxes in both hemispheres: Global and regional mercury cycling implications. Global Biogeochem Cycles 16(4): 1-51.

105. Streets DG, Lu Z, Levin L, ter Schure AFH, Sunderland EM (2018) Historical releases of mercury to air, land, and water from coal combustion. Sci Total Environ 615: 131-140.

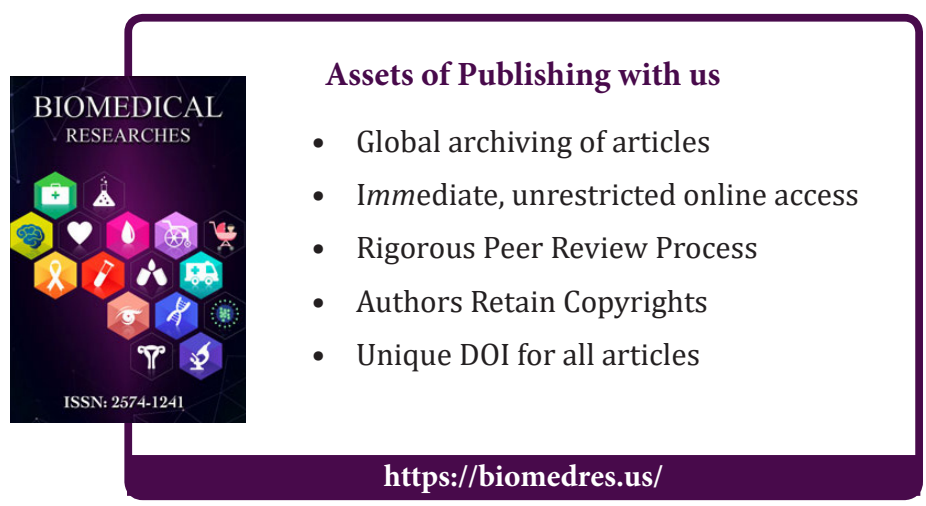

Cite this article: Timothy E E, Ali S, Carrie A S, Rajnish S, Yazeed A, et al. Strategies for Remediating Environmental Pollution, and Applicable Indicators for Identifying them: Mini Review. Biomed J Sci \& Tech Res 13(3)-2019. BJSTR. MS.ID.002390. D0I: 10.26717/ BJSTR.2019.13.002390. 